\title{
Sting Nematode, Belonolaimus longicaudatus Rau (Nematoda: Secernentea: Tylenchida: Tylenchina: Belonolaimidae: Belonolaiminae) ${ }^{1}$
}

\section{W. T. Crow and A. S. Brammer ${ }^{2}$ \\ Introduction}

Sting nematodes are among the most destructive plant-parasitic nematodes on a wide range of plants. Adults can reach lengths greater than $3 \mathrm{~mm}$, making them one of the largest plant-parasitic nematodes. While there are several species of sting nematodes described, only Belonolaimus longicaudatus Rau is known to cause widespread crop damage.

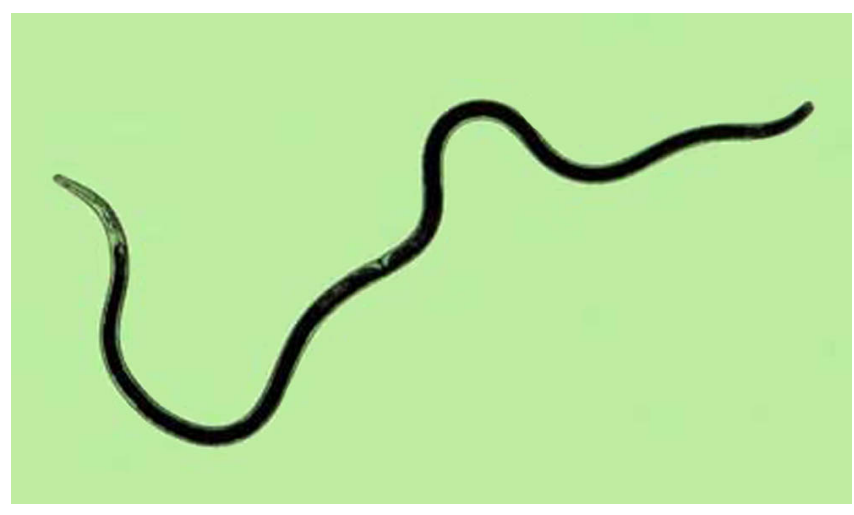

Figure 1. The adult female sting nematode Belonolaimus longicaudatus Rau. Credits: J.D. Eisenback, Virginia Polytechnic Institute and State University

\section{Distribution}

Belonolaimus longicaudatus is found primarily in the sandy coastal plains of the Atlantic and Gulf coasts but also occurs naturally in sandy areas of some Midwestern plains states such as Kansas and Nebraska. Sting nematodes can be introduced to new areas on infested turf sod and have been introduced by this means to some golf courses in California and internationally to some of the Caribbean islands, Puerto Rico, Bermuda and Australia. Sting nematodes require at least 80 percent sand content in soil to survive, so they are typically only found in sandy soil environments.

\section{Life Cycle and Biology}

Sting nematodes are ectoparasites of plant roots, meaning that they remain in the soil and feed by inserting a long stylet or mouth spear into root tips. The nematodes then inject enzymes into root tissues and suck plant juices out through the stylet. Root tips typically cease growing in response to feeding by sting nematodes. Sting nematodes cause particular

1. This document is EENY-239, one of a series of Featured Creatures from the Entomology and Nematology Department, Florida Cooperative Extension Service, Institute of Food and Agricultural Sciences, University of Florida. Published: September 2001. This document is also available on Featured Creatures Website at http://creatures.ifas.ufl.edu. Please visit the EDIS Website at http://edis.ifas.ufl.edu. Additional information on these organisms, including many color photographs, is available at the Entomology and Nematology Department website at http://entnemdept.ifas.ufl.edu/.

2. W. T. Crow and A. S. Brammer, Entomology and Nematology Department, University of Florida, Gainesville, FL.

The Institute of Food and Agricultural Sciences is an equal opportunity/affirmative action employer authorized to provide research, educational information and other services only to individuals and institutions that function without regard to race, color, sex, age, handicap, or national origin. For information on obtaining other extension publications, contact your county Cooperative Extension Service office. Florida Cooperative Extension Service/Institute of Food and Agricultural Sciences/University of Florida/Christine Taylor Waddill, Dean. 
damage to young plants with a developing root system.

Sting nematodes reproduce sexually, so both males and females are common in soil. After mating the female lays eggs in pairs in the soil and will continue to lay eggs as long as food is available. The eggs hatch after about five days. The young nematodes must locate a plant root and begin feeding to survive. Once feeding commences the juvenile nematodes grow and undergo three molts before becoming adults. The total life cycle from egg to reproducing adult takes 18 to 24 days.

\section{Importance}

Sting nematodes cause yield losses in many crops and can cause complete crop destruction with severe infestations. Damaged crops include vegetables (carrot, corn, crucifers, beans, potato, etc.), fruits (citrus, strawberry, etc.), agronomic crops (cotton, peanut, sorghum, soybean, etc.), turfgrasses (Bahiagrass, Bermudagrass, St. Augustinegrass, zoysiagrass, etc.) and forest crops (pine trees).

Sting nematodes are recognized as the major nematode pest on golf courses in Florida. Because of the sandy native soils in much of the state these nematodes are damaging on greens, fairways and even roughs. Because putting greens are typically constructed with high sand content they may harbor sting nematodes even when native soils are not sandy enough to support them. Many golf course greens in central Texas are infested with sting nematodes even though the native soil is heavy clay that will not support the nematodes.

\section{Symptoms}

Plants damaged by sting nematodes often wilt, may be stunted and may show symptoms of nutrient deficiency. Seedlings may sprout from the soil and then cease growing altogether. Plant death may occur with high population densities of sting nematodes. On turfgrasses, damage usually shows up in irregular patches. Often, sting nematode damage to turf is accompanied by proliferation of weeds such as spurge, sedge or Florida pusley.
All of these symptoms may be caused by a number of plant diseases and disorders. Therefore, the only way to be certain whether sting nematodes are a problem is to have a soil nematode assay conducted by a credible diagnostic facility.

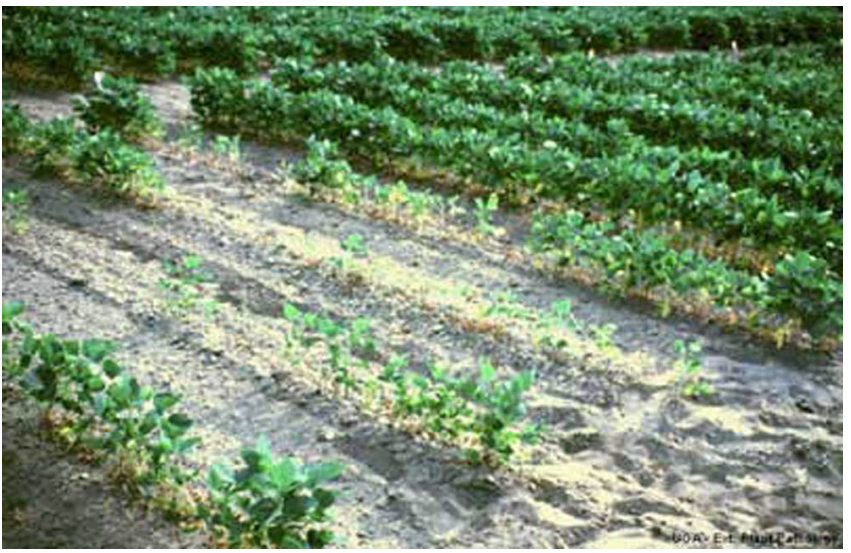

Figure 2. Sting nematodes (Belonolaimus longicaudatus Rau) cause stunting, yellowing and poor stand of soybeans. Credits: University of Georgia

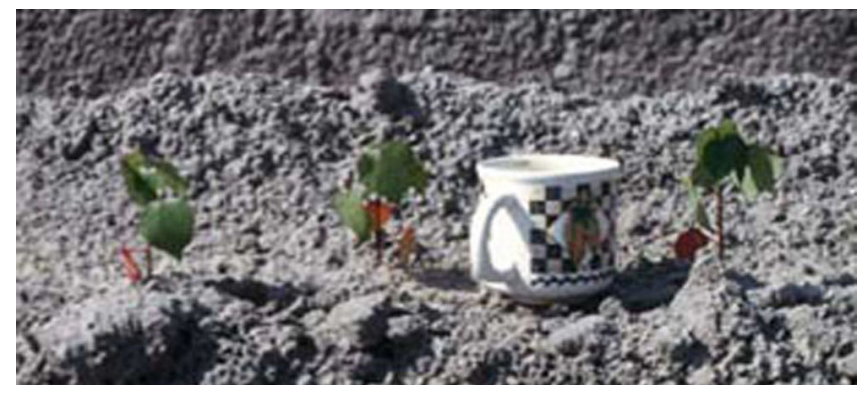

Figure 3. Fifty-day-old cotton plants grown in soil infested with sting nematodes (Belonolaimus longicaudatus Rau). Plants on the left are in untreated soil. Plants on the right are in soil treated with a nematicide. Credits: W.T. Crow, University of Florida

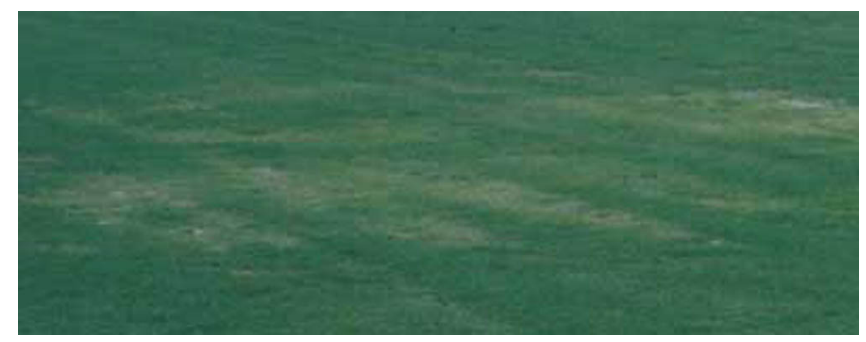

Figure 4. Sting nematode (Belonolaimus longicaudatus Rau) damage on turfgrasses usually appears as irregular patches of declining grass. Credits: W.T. Crow, University of Florida

\section{Hosts}

Sting nematodes can feed on more types of plants than almost any other nematode. Populations of sting 


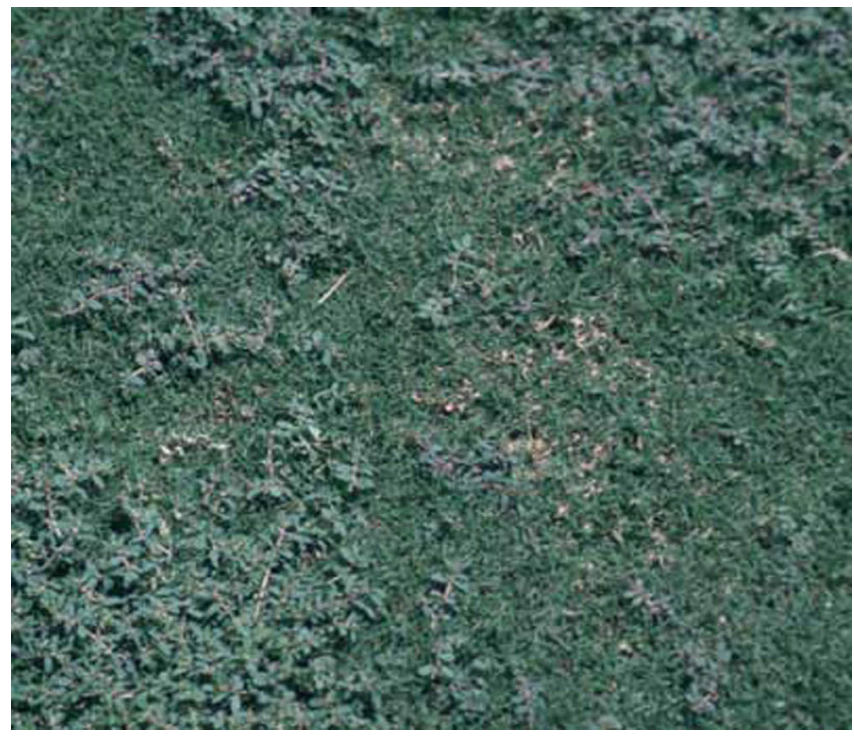

Figure 5. Sting nematode (Belonolaimus longicaudatus Rau) damage in turf is often accompanied by proliferation of weeds such as spurge. Credits: R.A. Dunn, University of Florida

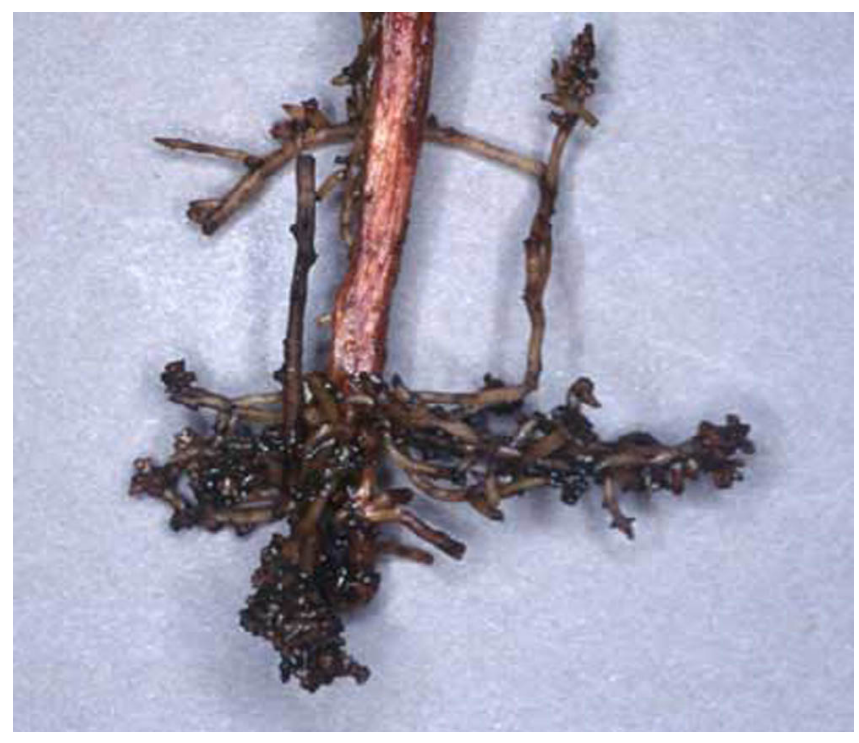

Figure 6. Cotton roots damaged by sting nematodes (Belonolaimus longicaudatus Rau) often are abbreviated or "stubby" looking. Credits: W.T. Crow, University of Florida

nematodes from different localities have been shown to differ in their ability to feed on some plants. For instance, they are known to be very damaging to peanut in the Carolinas, but populations in Florida do not attack peanut. Some populations in Florida are damaging to citrus, but others are not. It is possible that the host status of a particular type of plant varies according to the population of sting nematodes at a given locality.

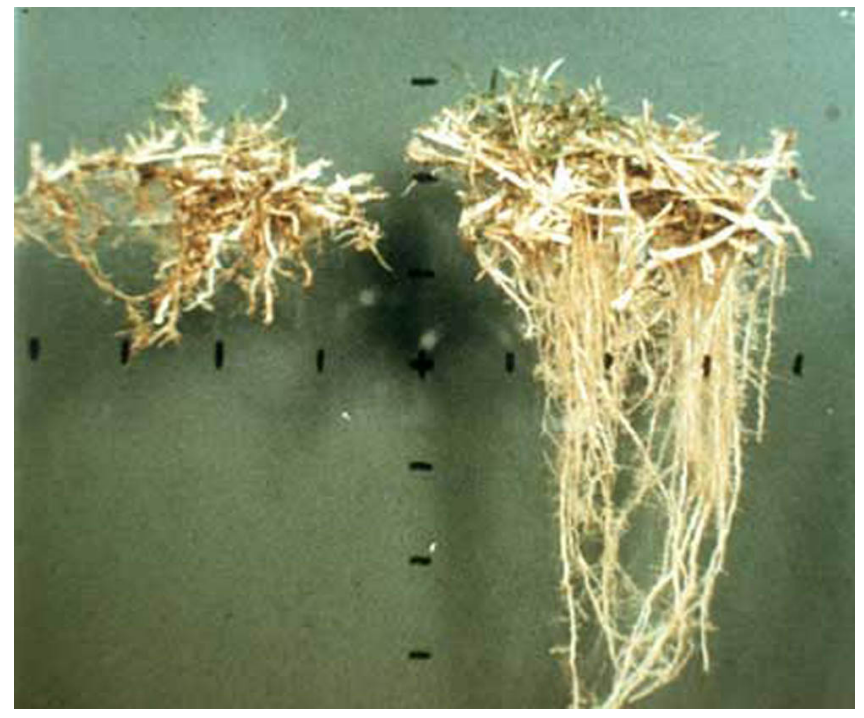

Figure 7. Turf roots that are damaged by sting nematodes (Belonolaimus longicaudatus Rau) often appear "cropped off" below the soil surface. Credits: R.A. Dunn, University of Florida

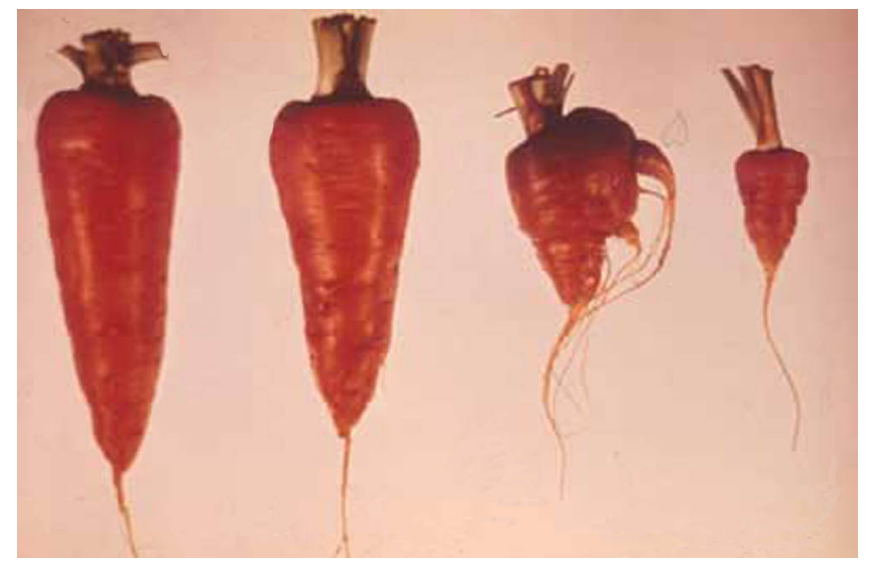

Figure 8. Sting nematodes can cause stunting of root crops such as carrot. The two carrots on the left are healthy, while the two carrots on the right are damaged by the sting nematode (Belonolaimus longicaudatus Rau). Credits: R.A. Dunn, University of Florida

Some plants that have proven to be good hosts to some populations of sting nematodes are given below. Asterisks indicate plants that are hosts for some populations of sting nematodes and not others.

Grain, turf and forage grasses: Bahiagrass, barley, bentgrass, Bermudagrass*, bluegrass, centipedegrass, corn, fescue*, millet, oats, Pangola digitgrass, St. Augustinegrass, Sudangrass, rye, wheat and zoysiagrass.

Fruits and vegetables: beans*, blueberry*, cabbage*, cantaloupe, carrot, cauliflower, cucumber*, endive, celery, citrus*, cowpea, 


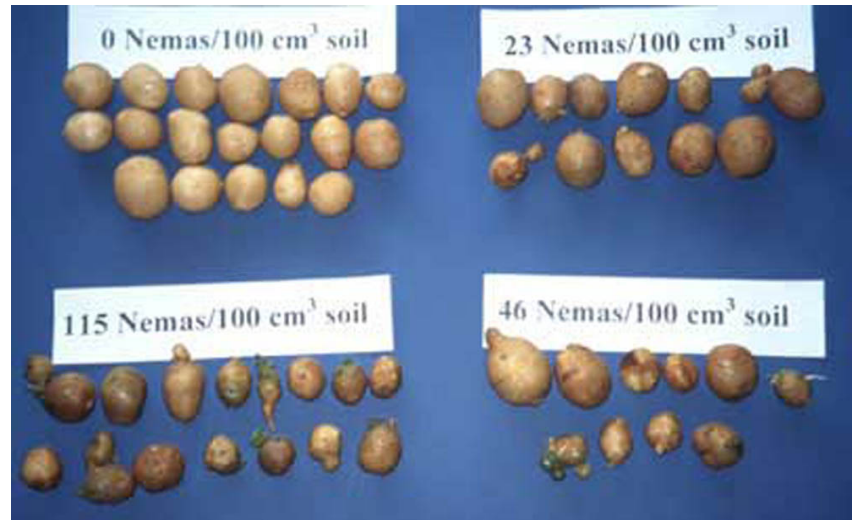

Figure 9. Potato tubers being fed on by sting nematodes may be stunted and misshapen. The effect of increasing population densities of sting nematodes (Belonolaimus longicaudatus $\mathrm{Rau}$ ) on potato tubers is visible here. Credits: W.T. Crow, University of Florida

eggplant*, lettuce*, muscadine grape, okra*, onion*, pea, pecan, pepper*, potato, squash, strawberry*, sweet potato*, tomato, turnip* and watermelon*.

Nongrass agronomic crops: cotton*, clover, peanut*, loblolly pine*, soybean and sugarcane.

Cover crops: hairy vetch, iron clay pea, joint vetch, lespedeza, mung bean, pidgeonpea, sesbania and sorghum-sudangrass.

Weeds: beggarweed, cocklebur*, crabgrass, cudweed, dandelion*, dogfennel, Johnsongrass, lambsquarter*, morning glory, Spanish needle*, ragweed and wild carrot.

Some plants identified as nonhosts or poor hosts in research studies include alfalfa, asparagus, camellia, cocklebur, crotalaria, gladiolus, hairy indigo, horseweed, hot pepper, Japanese holly, Jerusalem oak, jimson weed, okra, oxalis, pepper, plantain, pokeweed, sandbur, sunn hemp, tobacco and velvetbean. Because of the tremendous variation in ability to parasitize different plants exhibited by sting nematodes, there is no guarantee that these plants may not be hosts for untested populations.

\section{Management}

For the most current recommendations for nematode management on a particular crop, see:

University of Florida Nematode Management Guide (http://edis.ifas.ufl.edu/MENU_NG)
For current recommendations in some special crops, see:

Nematode Management for Golf Courses (http://edis.ifas.ufl.edu/IN124)

Nematode Management for Nonresidential Lawns, Athletic Fields, Racetracks and Cemeteries in Florida (http://edis.ifas.ufl.edu/IN126)

Nematode Management for Sod Production in Florida (http://edis.ifas.ufl.edu/IN125)

\section{Selected References}

- Abu-Gharbieh, W.I., and V.G. Perry. 1970. Host differences among populations of Belonolaimus longicaudatus Rau. Journal of Nematology 2:209-216.

- Perry, V.G., and H. Rhoades. 1982. The genus Belonolaimus. Pp. 144-149 in R.D. Riggs ed., Nematology in the southern region of the United States. Southern Cooperative Series Bulletin 276. Fayetteville, AR: University of Arkansas Agricultural Publications.

- Robbins, R.T., and K.R. Barker. 1973. Comparisons of host range and reproduction among populations of Belonolaimus longicaudatus from North Carolina and Georgia. Plant Disease Reporter 57:750-754.

- Smart, G.C. and K.B. Nguyen. 1991. Sting and awl nematodes. Pp. 627-668 in W.R. Nickle ed., Manual of agricultural nematology. Marcel Dekker Inc., NY. 